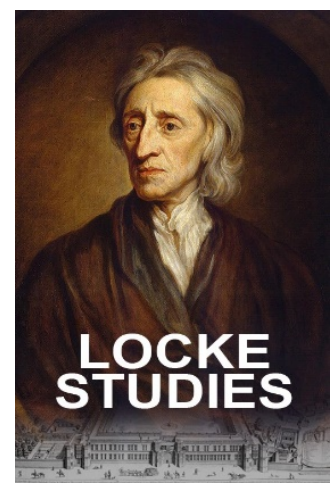

LOCKE STUDIES

Vol. 21

https://doi.org/10.5206/ls.2021.13725 | ISSN: 2561-925X

Submitted: 25 FEBRUARY 2021

Published online: 28 FEBRUARY 2021

For more information, see this article's homepage.

(C) 2021. Samuel C. Rickless

\title{
Corrigendum and Errata to Samuel C. Rickless's "Locke on the Probability of the Mind's Immateriality," Locke Studies 20 (2020): 1-28, https://doi.org/10.5206/ls .2020.10677
}

\author{
SAMUEL C. RICKLESS (UNIVERSITY OF CALIFORNIA, SAN DIEGO)
}

Abstract:

This article contains corrections to Rickless's article "Locke on the Probability of the Mind's Immateriality" published in Locke Studies 20 (2020). The original article may be found at the article' homepage. Rickless provides a corrigendum to his interpretation of Nicholas Jolley's Locke's Touchy Subjects. The editor notes three errata, which have been corrected in the original article.

Keywords: correction of publication

Locke Studies is published by Western Libraries at The University of Western Ontario.

This is an open access article published under the terms of the Creative Commons Attribution-Non Commercial-ShareAlike 4.0 International license, which permits use, distribution and reproduction in any medium, provided the original work is properly cited and shared under the original license. 


\section{Corrigendum}

In my original article, ${ }^{1}$ I describe Jolley as holding the view that Locke leans towards immaterialism of mind. ${ }^{2}$ Jolley contacted me to point out that this is not his view. Upon further review, I acknowledge that this is a misdescription and I regret the error. Jolley claims that "Locke leans in the direction of materialism," 3 on the strength of arguments that overlap at least partially with the arguments advanced by Downing and Hamou. 4 At the same time, as I (over)emphasize in the article, Jolley recognizes that Locke asserts "that the immateriality of the human mind is more probable than the thinking-matter hypothesis," 5 and does not question Locke's sincerity, leaving it a "mystery" what grounds Locke could have had for making the assertion. Jolley explores the possibility that Locke might have relied on the "image-of-God" doctrine, ${ }^{6}$ but finds the textual evidence for such reliance lacking. In the article, I argue that appeal to the "image-of God" doctrine would have been insufficient for Locke's purposes in any case.

\section{Errata}

The editor notes a correction to the spelling of Philippe Hamou's given name in footnote 5, corrected to "Philippe" from "Phillipe". The editor also notes a correction to the publication information on the original article's title page: the numeral expressing the volume number was listed twice, and the second instance has been eliminated, correcting it to "20" from "2020". The formatting of the author's affiliation has also been corrected: a line break has been removed and it now appears on the same line as the author's name.

${ }^{1}$ Samuel C. Rickless, "Locke on the Probability of the Mind's Immateriality," Locke Studies 20 (2020): 1-28, https://doi.org/10.5206/ls.2020.10677.

${ }^{2}$ Nicholas Jolley, Locke’s Touchy Subjects: Materialism and Immortality (Oxford: Oxford University Press, 2015).

3 Jolley, Touchy Subjects, 8.

4 Lisa Downing, "Locke's Choice between Materialism and Dualism," in Locke and Leibniz on Substance, eds. Paul Lodge and Tom Stoneham (New York: Routledge, 2015), 128-45 and Philippe Hamou, "L'opinion de Locke sur la 'matière pensante'," in John Locke, vol. 3 Metaphysics, ed. Peter R. Anstey, Critical Assessments of Leading Philosophers, Series II (London: Routledge, 2007), 169-216.

5 Jolley, Touchy Subjects, 98.

${ }^{6}$ Jolley, Touchy Subjects, 96-98. 